\title{
IAMJ
}

INTERNATIONAL

AYURVEDIC

MEDICAL JOURNAL

\section{AN ANALYTICAL STUDY ON VALMIKA MRITTIKA (ANTHILL SOIL)}

\author{
M. Sindhushree ${ }^{1}$, Prashanth Jain ${ }^{2}$, Subrahmanya Padyana ${ }^{3}$ \\ ${ }^{1}$ Final Year BAMS, ${ }^{2}$ Associate Professor, Department of Roganidana, ${ }^{3}$ Director, \\ Alva's Traditional Medicine Archive \& Research Centre, Moodubidire, Karnataka, India
}

Email: sindhusriatreya@yahoo.com

\section{https://doi.org/10.46607/iamjp04042020}

(Published online: May 2020)

Open Access

(C) International Ayurvedic Medical Journal, India 2020

Article Received: 27/03/2020 - Peer Reviewed: 07/05/2020 - Accepted for Publication: 23/05/2020

\section{Check for updates}

\section{ABSTRACT}

Valmika Mrittika (ant hill soil) is widely used in clinical practice by folklore practitioners in most of the skin ailments. Lepa of Valmika Mrittika has wonderful effects on skin. Many temples in South Canara, give this Valmika Mrittika as Prasadam for the skin disorders. Acne Vulgaris is a common skin disorder of pilosebaceous unit that primarily affects the face, chest and back which if not treated may lead to permanent scarring. Youvana Pidaka (Acne vulgaris) occurs due to vitiation of Kapha, Vata as Doshas, Rakta and Twak as Dooshyas. Valmika Mrittika is very effective in Kapha-Vataja disorder. As disease limited to skin, Lepa Chikitsa is most suitable and convenient treatment suggested for acne. Hence, an in vitro analytical study of Valmika Mrittika w.s.r to Youvana Pidaka (Acne vulgaris) was conducted. Valmika Mrittika collected and analytical study was done including macronutrients and micronutrients. Analytical study revealed the contents such as Protein $-800 \mu \mathrm{g} / \mathrm{g}$, Phenols$0.03 \mu \mathrm{g} / \mathrm{g}$, Tannins- $0.24 \mu \mathrm{g} / \mathrm{g}$ in the sample of Valmika Mrittika which are found to have anti acne and Varnya properties.

Keywords: Analytical study, Valmika Mrittika, Youvana Pidaka, Acne vulgaris

\section{INTRODUCTION}

In the present era, physical appearance carries a very important role as it is one among the factor for a person to be fit. Youvana Pidaka is a burning issue in the society. Though it is not life threatening, it causes 
psychological upset and worries to the person. 'Youvana Pidaka' as the name suggests is considered as adolescent disorder. People are more cautious about outer looks and Youvana Pidaka makes one to look unattractive. Acne by definition is multifactorial chronic inflammatory disease of pilosebaceous units, leads to papular, pustular, and cystic leisons more prominently on the face ${ }^{1,2}$.

Though, Youvana Pidaka's are categorized under Kshudra Roga by Acharya Sushrutha, ${ }^{3,4}$, it tops in the cosmetic and dermatological problems in almost all the world population as it leaves the 'scar', even after many years .Youvana Pidaka (Acne vulgaris)is caused due to involvement of Kapha, Vata and Rakta ${ }^{5,6,7,8,9}$. An in vitro study of Valmika Mrittika (ant hill soil) reveals the important contents acting on acne. Analytical study includes estimation of protein, phenol, tannin and other tests which has antiacne property.

\section{Materials and Methods}

For the present study, the drug Valmika Mrittika (Anthill soil) collected from the natural source near to Moodubidire. The anthill soil is was initially subjected to organoleptic evaluation, $\mathrm{pH}$ value and later subjected to various qualitative as well quantitative analysis of the sample such as estimation of protein (By Lowry's method $)^{10}$, estimation of Phenols ${ }^{11}$ and estimation of Tannins by Folin-Denis Method ${ }^{12}$ : The study was conducted at the Department of PG studies in Dravya Guna Vijnana, Alva's Ayurveda Medical College, Moodubidire and Department of PG studies in Biotechnology, Alva's College, Moodubidire.

\section{RESULT}

\section{Organoleptic test}

Taste - astringent (Kashaya RasaPradhan), Odour - no characteristic smell Color - brown Texture - granular

2. Determination of $\mathrm{pH}$ Value: $\mathrm{pH}$ value of the anthill soil is 5.29

3. Results of the qualitative analysis of the organic component in the anthill soil

\section{Table1}

\begin{tabular}{|l|l|l|}
\hline Sl. No. & Organic Component & Qualitative analysis \\
\hline 1. & Proteins & Present \\
\hline 2. & Phenols & Present \\
\hline 3. & Flavanoids & Present \\
\hline 4. & Tannins & Present \\
\hline 5. & Steroids & Absent \\
\hline 6. & Saponins & Present \\
\hline
\end{tabular}

4. Results of the quantitative analysis of the organic component in the anthill soil

Table 2

\begin{tabular}{|l|l|l|}
\hline S1. No. & Organic Component & Quantitative analysis \\
\hline 1. & Proteins & $800 \mu \mathrm{g} / \mathrm{g}$ \\
\hline 2. & Phenols & $0.03 \mu \mathrm{g} / \mathrm{g}$ \\
\hline 3. & Tannins & $0.24 \mu \mathrm{g} / \mathrm{g}$ \\
\hline
\end{tabular}

\section{DISCUSSION}

The people of Dakshina Kannada District are more prone to the skin diseases because of the food habits such as eating more of Fish, Brinjal etc. The nature has bestowed us an enormous amount of medicinal solutions for such diseases. As Valmika Mrittika is believed to be very effective in the treatment of various skin diseases, the present study is undertaken to study the chemical profile of the anthill soil and to analyse its role in the skin diseases especially on Youvana Pidaka (Acne vulgaris). 
Protein is important to help tighten skin. Protein helps in rejuvenating the cells and helps in growth of skin cells. Severe protein deficiency may affect the skin, causing redness, flaky skin and depigmentation. ${ }^{13}$ Evidence suggests that people can benefit from either by diet or through skin application of Phenol because they can alleviate symptoms and inhibits the development of various skin diseases including acne. Phenol is effective in pitted scars, pigmentations, and certain facial blemishes such as chloasma, rosacea, and xanthelasma. ${ }^{14}$. Phenolics exhibit antioxidant, antispasmodial and antimicrobial activities. Phenol and phenolic compound such as flavonoids have been shown to possess significant antioxidant activities. Antioxidant activity increased proportionally with the polyphenol content. They increase the tensile strength of muscle and skin. The utility of antioxidant therapies in many diseases is well recognized. Cellular damage arising from an imbalance between free radical generating and scavenging systems has been implicated in the pathogenesis of a wide range of disorders, including cardiovascular disease, cancer and aging. Phenolic compounds have capacity of reducing oxidative cellular damage caused by free radicals. Tannins have been found to form irreversible complexes with proline rich protein resulting in the inhibition of cell protein synthesis. Tannins are known to react with proteins to provide the typical tanning effect which is important for the treatment of inflamed or ulcerated tissues. The antimicrobial activities of tannins fight against bacterial infections (i.e., acne) and also act as an antioxidant against free radicals that cause cell damage. Tannins are also a natural astringent, which means they remove excess oil from the pores and tighten them without drying out the skin ${ }^{15}$. Valmika Mrittika is a potent drug having Kashaya Rasa (Astringent) that acts on Kapha Dosha of Youvana Pidaka.

\section{CONCLUSION}

Youvana Pidaka is commonest disorder which present with features - Papules, resembling the sprouts on the bark of Shalmali (Bombax ceiba),Medogarbha Pidaka ${ }^{16}$ (fat filled eruption)Occurs on Mukha (face),Occurs in

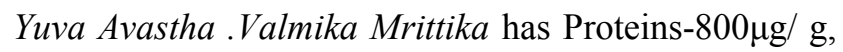
Phenol- $0.03 \mu \mathrm{g} / \mathrm{g}$ and Tannins-0.24 $\mu \mathrm{g} / \mathrm{g}$. When studied analytically. In vitro study of Valmika Mrittika proves to have Proteins, Phenols, Flavanoids, Saponins and Tannins there by it has anti acne properties.

\section{REFERENCES}

1. Simpson NB, Cunliffe WJ. Disorders of the sebaceous glands. In: Burns T, Breathnach S, Cox N, Griffiths C, editors.

2. https://finalstepmarketing.com/wpcontent/uploads/201 7/05/Acne-Demographic-Research-.pdf

3. Sushruta, Sushruta Samhitha, Dalhana commentary, Nibandhasangraha, Chowkambha Orientalia, Varanasi, 2009, Nidinasthana 13/39, page no 323

4. Sushruta, Sushruta Samhitha, Dalhana commentary, Nibandhasangraha, Chowkambha Orientalia, Varanasi, 2009, chikitsasthana 21/37, page no 480

5. Sushruta, Sushruta Samhitha, Dalhana commentary, Nibandhasangraha, Chowkambha Orientalia, Varanasi, 2009, Nidinasthana 13/39, page no 323

6. Shri Madhavakara, Madhava Nidana, English translation by Prof. K. R. Shrikanthamurty, Chaukambha Orientalia Publishers, edition 2011, chap no 55, shloka no 33, Page number 181.

7. Bhavamishra, Bhavaprakasha, English translation by Prof. K. R. Shrikanthamurty, Chaukambha Orientalia, Volume 2, edition -2009, Madhyamakhanda, Chapter no -61, shloka no 31, Page no -656

8. Acharya Yogaratnakara, English translation ad edited by Dr. Madham Shetty Suresh Babu, Published by Chaukambha Sanskrit Series office, $1^{\text {st }}$ edition 2008, Kshudrarogadhikara, Shloka no 34, Page no: 1008.

9. Shree Basavaraja, Basavarajeeyam, Edited by M.S. Krishnamurty, Chaukambha Orientalia, $1^{\text {st }}$ edition2014, 22/69, page no 602

10. Sadasivam, S. and Manickam, A. Biochemical methods. 3rd edn. New Age International Publishers, New Delhi, India, 2008.

11. Sadasivam, S. and Manickam, A. Biochemical methods. 3rd edn. New Age International Publishers, New Delhi, India, 2008.

12. Sadasivam, S. and Manickam, A. Biochemical methods. 3rd edn. New Age International Publishers, New Delhi, India, 2008.

13. https://www.healthline.com/nutrition/proteindeficiency-symptoms

14. https://www.jprasurg.com/article/S0007$1226(60) 80032-\mathrm{X} / \mathrm{pdf}$

15. https://verilymag.com/2017/11/tannin-witch-hazelskincare-adult-acne-toner-cleanser-witch-hazel-foracne-glycerin-ph-balance-thayers-witch-hazel-allnatural-skincare

16. Acharya Vagbhata, Ashtanga Hrudaya, with Sarvangasundara, Arunadatta commentary and 
Ayurveda Rasayana by Hemadri, Edited by Pt.

Harisadashiva Shastry Paradakara, Chaukambha

Surabharati Prakashan, Varanasi, Reprint - 2009, Uttarasthana $31 / 5$, page no. 888 .

\section{Source of Support: Nil}

\section{Conflict of Interest: None Declared}

How to cite this URL: M. Sindhushree et al: An Analytical Study on Valmika Mrittika (Anthill Soil). International Ayurvedic Medical Journal \{online\} 2020 \{cited May, 2020\} Available from:

http://www.iamj.in/posts/images/upload/2285_2288.pdf 